\title{
Systematic review on health care professionals' competencies in the care of LGBT+ individuals
}

\author{
Revisão sistemática sobre competências de profissionais \\ de saúde na assistência ao público LGBT+
}

\author{
Willian Roger DULLIUS1 ${ }^{1}$ 0000-0003-3144-378X \\ Lara Barros MARTINS ${ }^{1}$ iD 0000-0002-3175-6324 \\ Vanessa Monteiro CESNIK2 ID 0000-0002-1017-5512
}

\begin{abstract}
This review encompasses both national and international literature about training needs analyses for health care professionals working with the LGBT+ population. The descriptors "health professionals", "health providers", "LGBT", "training needs analysis" were searched in the following databases: Academic OneFile, Academic Search Complete, Medical Literature Analysis and Retrieval System Online, Virtual Health Library, Cumulative Index to Nursing and Allied Health Literature, Complementary Index, Business Source Complete, Education Source, Gender Studies, National Center for Biotechnology Information, Scientific Electronic Library Online, SportDiscus, and PsycINFO. Inclusion criteria were: empirical articles, published from 2007 to 2017, in indexed and peer-reviewed journals, available in full text, in Portuguese or English versions. Of the 17 included articles, most were published in North American countries. There is a need for training and formal protocols within institutions. Training had positive results. No instruments about the competencies for health care professionals working with the LGBT+ population were identified. Further studies should be conducted in the field of health care professionals training to provide satisfactory health care services to this public.
\end{abstract}

Keywords: Health personnel; People LGBT; Personnel training; Training analysis.

\section{Resumo}

Revisar a literatura nacional e internacional quanto à análise de necessidades de treinamento para profissionais de saúde no atendimento ao público LGBT+. Os descritores "health professionals", "health providers", "LGBT", "training needs analysis"

$\checkmark v \nabla v$

1 Faculdade Meridional, Escola de Saúde, Programa de Pós-Graduação em Psicologia. R. Senador Pinheiro, 304, Vila Rodrigues, 99070-220, Passo Fundo, RS, Brasil. Correspondência para/Correspondence to: W.R. DULLIUS. E-mail: <rogerdullius@gmail.com>.

2 O Corpo Explica Treinamentos, Departamento Cientifico. São José dos Campos, SP, Brasil.

Article based on the dissertation of W.R. DULLIUS, entitled "Avaliação de necessidades de treinamento em profissionais de saúde na assistência humanizada a indivíduos LGBT+". Faculdade Meridional, 2018.

$\boldsymbol{\nabla} \mathbf{v} \boldsymbol{\nabla}$

Como citar este artigo/How to cite this article

Dullius, W. R., Martins, L. B., \& Cesnik, V. M. (2019). Systematic review on health care professionals' competencies in the care of LGBT+ individuals. Estudos de Psicologia (Campinas), 36, e180171. http://dx.doi.org/10.1590/1982-0275201936e180171 
foram pesquisados nas seguintes bases de dados: Academic OneFile, Academic Search Complete, Medical Literature Analysis and Retrieval System Online, Biblioteca Virtual em Saúde, Cumulative Index to Nursing and Allied Health Literature, Complementary Index, Business Source Complete, Education Source, Gender Studies, National Center for Biotechnology Information, Scientific Electronic Library Online, SportDiscus e PsycINFO. Os critérios de inclusão utilizados foram artigos empíricos, publicados entre 2007-2017, em revistas indexadas e avaliação por pares, textos na íntegra, em português ou inglês. Nos 17 artigos selecionados prevaleceram publicações norte-americanas; há uma carência de capacitações e de protocolos científicos em instituições; os treinamentos realizados tiveram resultados positivos; e nenhum instrumento sobre competências de profissionais de saúde na assistência ao público LGBT+ foi identificado. Pesquisas devem ser realizadas no domínio de capacitações dos profissionais de saúde para prestar assistência satisfatória a esse público.

Palavras-chave: Pessoal da saúde; Pessoas LGBT; Treinamento de pessoal; Análise didática.

Human sexuality is a subject that still has a small presence and little debate in the curricula and in the capacities of health care professionals, and this is further restricted when it involves the specific care of the LGBT+ (Lesbian, Gay, Bisexual, Transvestite and the + sign for other gender designations: Transsexuals, Transgender, Queer, and Intersex Individuals) population (Cesnik \& Zerbini, 2017; Rowan \& Beyer, 2017; Talan, Drake, Glick, Claiborn, \& Seal, 2017). Influences on the lack of training offered in this topic may be due to the socio-historical context based on concepts and debates that go back to the heterosexual binary matrix, which remains a regulating system of sexuality and subjectivity (Chapman, Watkins, Zappia, Nicol, \& Shields, 2012b).

Brazil leads the world ranking of murders and sexual violence against LGBT+. According to the report by Mott, Michels, and Paulino (2017), every 19 hours an LGBT+ person is murdered violently due to homophobia in the country. In 2017, 445 people were registered victims of homotransphobia, and there is an expectation that these statistics will rise. Leading a world ranking in the XXI century indicates that there are serious flaws in the education of the population. In the context of health care, there is a history of LGBT+ being verbally harassed by health care professionals, indicating a greater need for awareness-raising and training actions for these professionals (Rowan \& Beyer, 2017).

In this sense, there is a need to promote learning opportunities and educational actions capable of raising awareness about sexual diversity and respect for the human being so that LGBTphobia is no longer part of the everyday life in the health care area. To ensure this, it is important to guarantee that professionals working in the context of health care and prevention are fully prepared to serve this population.

In addition to the increased risk of being murdered, there are other problems that people in the LGBT+ community experience at a variety of ages. Lesbian, Gay, Bisexual, Transvestite adolescents have a higher suicidal ideation, higher rates of suicide attempts, and suffer more sexual violence than heteronormative adolescents; homosexual men, along with other non-heteronormative individuals, are more vulnerable to depression and suicide; transsexual individuals have a high incidence of anxiety disorder, depression and higher rates of suicide attempts (Lerri et al., 2017; Lee, Oliffe, Kelly, \& Ferlatte, 2017; Teixeira Filho \& Rondini, 2012). In this way, health care professionals should focus on their care beyond Sexually Transmitted Infections (STIS) (Ferlatte, Salway, Oliffe, \& Trussler, 2017). By recognizing the risk factors, stigma, invisibility, and vulnerabilities these people face in their daily lives, health care providers can properly conduct health care in preventing depression and suicide (Lee et al., 2017; Merryfeather \& Bruce, 2014). This will be made possible through greater education actions on sexuality and gender diversity in the health care context, as well as advocating for change in the health care model for these minorities to effectively promote the health of this population (Harrell \& Sasser, 2018).

Still a result of this socio-historical-cultural context, marked by prejudice and the pathologization of human sexuality, the provision of health care and daily clinical practices are most often guided by the 2 psychiatrisation of homosexuality and transsexuality. The diagnosis of gender identity disorder, for example, 
can be considered a pathological and stigma vector, since it attributes a disease to the patient without questioning the historical, political and subjective issues of this psychiatrisation. Thus, a normative system of sex and gender is reproduced that does not correspond to the modes of subjectivation or the diversity of the gender-building forms in transsexuality, besides not letting patients express themselves (Arán, Murta, \& Lionço, 2009; Moscheta, Souza, \& Santos, 2016).

Although there have been some changes in society, such as the insertion of laws that guarantee the use of the individual's chosen name, there are still many barriers in the health system, which limit an improvement in the results of non-heterosexual young individuals, i.e., essential services such as hormonal drugs and sex reassignment surgeries (Dowshen et al., 2016). In order for prejudice and violence towards LGBT+ individuals to cease to exist, and for adequate health care be offered, it is necessary to review the current cultural concepts of the health care team through training in this subject so that these problems can be minimized or even extinguished, providing positive results in health care for the LGBT+ population (Merryfeather \& Bruce, 2014).

And how to assess what aspects are really needed to be worked on in training? The Training Needs Assessment (TNA) area is part of the Training, Development and Education (TD\&E) system and anticipates the educational event itself, by conducting an assessment of the existing or unsatisfactory competencies in the group of individuals that will be the target of the training (Meneses, Zerbini, \& Abbad, 2010). This step allows the collection and analysis of information, technical and/or behavioral skills that must be transmitted, as well as differentiating the professionals which really need to deepen their knowledge.

Given this scenario, which highlights the need for LGBT + people and the gap in the context of training health care professionals about the health care of this population, this article aims to describe what Brazilian and foreign literature have produced of empirical knowledge that indicate which are the training needs of health care professionals in assisting LGBT+ individuals.

\section{Method}

A systematic review is a research method that presents a rigorous and judicious process of collection and critical evaluation of research results, as well as reducing bias by identifying, evaluating, and synthesizing all relevant studies of the research topic, and not only those compatible with the researcher's hypotheses or theoretical-methodological perspectives (Costa \& Zoltowski, 2014; Uman, 2011).

It involves a detailed and comprehensive plan, and uses research strategies to analyze the production of knowledge in the scope of study. According to the guidelines of Rojon, McDowall, and Sounders (2011), the systematic review is developed in three stages, with pre-established criteria, so that there is an adequate search of the publications in the databases, which are: (1) transparency, specificity, and repetition of the study compared with the narrative review; (2) the process of constructing the research question must be carried out with the guidance of professionals of the area, a fact that offers theoretical rigor and practical relevance when carrying out the review; and (3) the research must use concise inclusion and exclusion criteria.

In this work, the systematic review protocol proposed by Cronin, Ryan, and Coughlan (2008) was adopted, which is composed of the following steps: (1) formulation of the question used for searching; (2) establishment of a set of inclusion and exclusion criteria; (3) literature selection and access; (4) evaluation of the quality of the literature included in the review; and (5) analysis, synthesis and dissemination of results.

The article search used the descriptors "health professionals" OR "health providers" AND "LGBT" AND "training needs analysis" and their Portuguese language correspondents: "profissionais de saúde" OR "provedores de saúde" AND "LGBT" AND "análise de necessidades de treinamento"; the inclusion criteria 
consisted of the search for empirical articles that addressed the subject of interest, with qualitative and quantitative delineations, published in the last ten years (2007-2017) in indexed and peer reviewed journals, available in full text, and of free access, in Portuguese or English. The exclusion criteria were duplicate publications in the databases, and those that addressed the issue of sexual minorities, but not the analysis of training needs, simultaneously.

The databases consulted for this systematic review were: Academic OneFile, Academic Search Complete, MedLine, Bireme (Latin American and Caribbean Center for Health Sciences Information), CINAHL (Cumulative Index to Nursing and Allied Health Literature), Complementary Index, EBSCOhost, Education Source, Gender Studies, NCBI (National Center for Biotechnology Information), SciELO (Scientific Electronic Library Online), SportDiscus/EBSCOhost and PsycINFO (American Psychological Association).

When searching the databases, firstly, the title and the summary of the articles found were read in order to verify if they related to the research subject; after performing this first screening, the articles collected were read in full to deepen into the subject described and to check the framing of the article in relation to the topic of interest. A total of 17 articles were selected to compose the present review. Figure 1 shows the results, in quantitative terms, of the searches performed in the abovementioned databases. In the SciELO, EBSCOhost and PsycINFO databases, no articles were found according to the inclusion criteria established for this review.

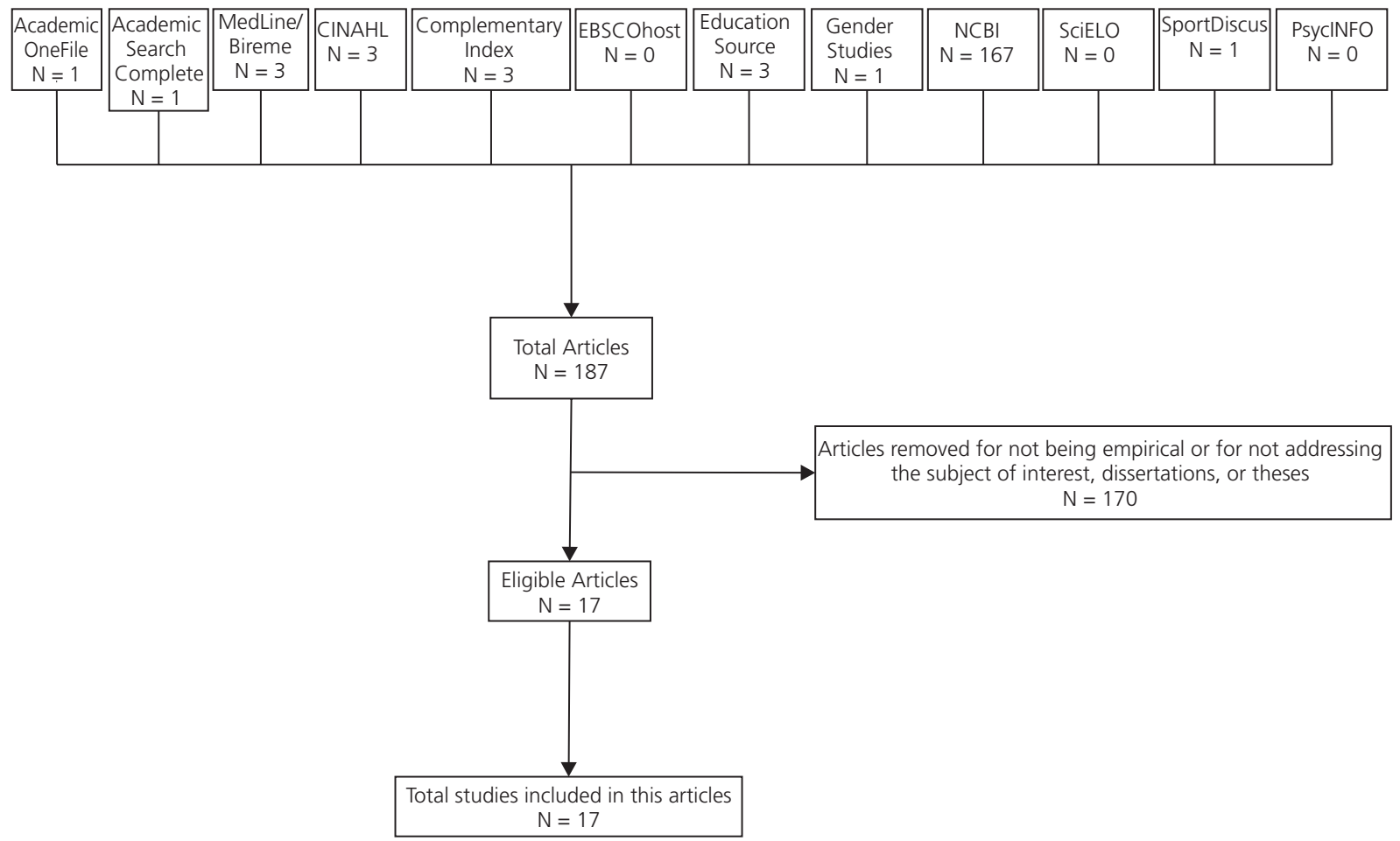

Figure 1. Information flowchart of the steps performed in the systematic review.

Note: CINAHL: Cumulative Index to Nursing and Allied Health Literature; NCBI: National Center for Biotechnology Information; PsycINFO: American Psychological Association; SciELO: Scientific Electronic Library Online.

\section{Results and Discussion}

Table 1 presents the following information about the studies that make up this literature review: authors, place, country and year of research, objective, method, number of participants, and main results obtained. 
Table 1

Description of the articles that compose this literature review

\begin{tabular}{lll}
\hline Author & Goal / Method / Sample & \multicolumn{1}{c}{ Main results } \\
\hline Ash \& Mackereth & To describe the access of & Participants reported negative feelings \\
(2013) / Surderland / UK & LGBT individuals to the & and experiences related to stigma, \\
& health system in the north of & discrimination and feeling of being \\
& England / Qualitative / 130 an invisible individual for health care \\
& patients. & professionals.
\end{tabular}

Beagan, Fredericks, \& Bryson (2015) / Halifax and Vancouver / Canada

Bidell (2017) / U.S.A. and United Kingdom
To analyze the experience and the understanding of doctors about patients who identify themselves as LGBTQ / Qualitative / 24 doctors.
Restriction on teaching about the health of LGBTQ individuals (especially transgender individuals) at the university, but there were lessons about homosexuality as a psychiatric diagnosis.

From the perspective of professionals, they provide equal care for all patients as individual human beings.

To validate the Clinical Skills Development Scale for Lesbian, Gay, Bisexual and Transgender Individuals (LGBT-DOCSS) / Quantitative / 602 health care professionals.
The LGBT-DOCSS scale can be used to determine the LGBT clinical development, explore specific clinical features, or when developing or testing various programs or training methods related to the LGBT topic.
Professionals are interested in training
Carabez et al. (2015) / San Francisco / U.S.A.

To report nurse training and explore the reasons for feeling uncomfortable in the health care of LGBT individuals / Mixed / 268 nurses.

Chapman, Watkins, Zappia, To explore and describe the Combs, \& Shields (2012) / experience of LGBT parents Melbourne / Australia in accessing the health care system for their children / Qualitative / 11 patients.
To elaborate a "pocket book" on how to provide health care for Queer individuals.

By specifically examining the score of each topic on the LGBT-DOCSS scale, it can be used to guide studies and training courses. or would like more information however, the lack of training in their work institutions provides discomfort in their professional practices.

The perception of couples about the need for a greater sensitivity and the awareness of training for health care professionals who cared for their children.

The need to integrate the health of LGBT individuals into the nursing education system, as well as training in orientation and cultural diversity for health care professionals.

Further studies involving more transgender parents will be valuable. Health care institutions should provide policies and standards that are not heteronormative, so professionals should provide health care for LGBT families with inclusive nondiscriminatory care.

The need for training health care professionals in relation to the needs and concerns of elderly LGBT individuals. and their need for health care / Qualitative / 124 patients. discrimination of the health care system; the need for resources and supporting actions for programs that provide health care. 
Table 1

Description of the articles that compose this literature review

\begin{tabular}{|c|c|c|}
\hline Author & Goal / Method / Sample & Main results \\
\hline $\begin{array}{l}\text { Jabson, Mitchell, \& Doty } \\
\text { (2016) / Tennessee / U.S.A. }\end{array}$ & $\begin{array}{l}\text { To verify how the policies } \\
\text { are related between the } \\
\text { knowledge, attitudes and } \\
\text { gender of doctors with the } \\
\text { affirmative actions of sexual }\end{array}$ & $\begin{array}{l}\text { Generally speaking, doctors have most } \\
\text { of the negative attitudes towards } \\
\text { transsexual patients and have negative } \\
\text { attitudes with less intensity in relation } \\
\text { to cisgender patients. }\end{array}$ \\
\hline
\end{tabular}
minorities / Quantitative / 180 doctors.

Mahdi, Jevertson, Schrader, To examine the knowledge, Nelson, \& Ramos (2014) / attitudes and skills of school New Mexico / USA

counselors, social workers and nurses about LGBTQ young individuals in health risk situations / Quantitative / 183 school health care professionals (57 school counselors, 83 nurses and 43 social workers).

Matharu, Kravitz, McMahon, To check the attitude of Wilson, \& Fitzgerald (2012) / medical students against California / USA the behavior of gay men / Quantitative / 251 health field students.
Most health care professionals demonstrated moderate-level knowledge on the behavioral health risks of LGBT young individuals;

Nurses demonstrated the lowest level of knowledge related to behavioral health risk issues; other professionals expressed high rates of negative attitudes towards gay and lesbian individuals.

There is a moderate significance by students regarding negative attitudes toward gay people, since the analyzes demonstrate how American students behave negatively with gay men, but they do not characterize their perceptions of lesbian, bisexual, transgender, or intersex individuals; Negative attitudes towards gay individuals are linked to normative conceptions of the masculine gender or how society imposes that the masculine gender should act, the attitudes played by men at young age.
Meyer \& Johnston (2014) / To evaluate an LGBT care training New York / USA course / Qualitative / 2,400 health care professionals.

Health care professionals had a high score in the pre-test, which suggested that the participants were well informed about the care given to elderly LGBT individuals prior to the training; the knowledge about how to provide a more welcoming environment for LGBT elderly individuals still increased significantly (post-test), although only two 4-hour training sessions had been available for them.

Moe \& Sparkman (2015) / To explore the perspective Norfolk / USA of LGBTQ service providers with individuals and LGBTQ communities / Quantitative / 109 patients.
The main form of professional barrier was discrimination due to the patient's sexual orientation; The training experience demonstrated a significant effect on the performance of professionals in assisting the LGBT population.
The need to revise the curriculum and add more disciplines on the health care of sexual minorities.
To offer more training options and online access to training for health care professionals regarding the LGBT public health care; to carry out trainings for caregivers of LGBT elderly individuals to meet their needs.
Further studies are needed to identify interdisciplinary patterns such as theoretical models for practical guidelines. 
Table 1

Description of the articles that compose this literature review

\begin{tabular}{lll}
\hline Author & Goal / Method / Sample & Main results
\end{tabular}

Moe \& Sparkman (2015) /

Norfolk / USA

Africa

Pelts \& Galambos (2017) / To make an intervention to Mississippi / USA

Poteat et al. (2017) / Baltimore / USA the members of the team who provide health care services to the residents of nursing homes / Mixed / 60 professionals.

To report the evaluation of the "Gender \& Sexual Diversity (GSD)" scale / Mixed / Quantitative - 1,766 professionals from 33 countries.

Qualitative - 29 professionals from 21 countries.

Rutherford, Mclntyre, Daley, To explore how caregivers \& Ross (2012) / Toronto / with practices focused on the Canada
LGBT public have developed their capacities regarding this population / Qualitative / 08 health care professionals.
Participants who were able to identify barriers in the workplace are probably professionals who had obtained training in the area or who have worked in places that care for LGBT individuals.

There is no exclusive course to teaching in the context of LGBT health.

Health care students should understand how social exclusion, stigma, and discrimination affect the health of LGBT individuals, and change their attitudes and assumptions so that they do not become "prejudiced" health care professionals.

After the intervention, there was a significant increase in positive attitudes towards assisting residents who identified themselves as lesbian and gay individuals.

Women showed lower negative attitudes than men.

Attitudes regarding SGM and gender differences were more positive after the training compared to the pre-training data; after the primary intervention, the professionals performed different interventions in the workplace or in the following GSD training programs.

Professionals had identified themselves as members of the LGBT community, but membership is not equal to providing adequate support or care for LGBT individuals

Knowledge gaps have been clarified through workshops and training materials, either independently or in a groups of professional colleagues working with the LGBT population. There is a lack of training opportunities in the LGBT field, as well as specific resources to promote awareness of mental health services in this field.

Snelgrove, Jasudavisius, To examine the difficulties Rowe, Head, \& Bauer (2012) / faced by doctors when caring Ontario/ Canada for transgender individuals / Qualitative / 13 doctors.
The biggest barrier was the identification, availability and quality of reference/ source of information about medical care for transgender people, situations that trigger barriers to the health care; the concept of "two-gender.
LGBT health should be incorporated into the existing curriculum to prepare health care students for providing decent care practices for LGBT individuals.
The evaluation of longitudinal studies and online or short-term training studies should be assessed to verify the impact of these courses on health care professionals.
Mandatory introduction of the LGBT health care context in medical schools: terminologies, appropriate intervention issues, minimizing disclosure of sexual orientation and gender identity, information on the impact of heterosexuality and homophobia, and the need for a specific health care practice oriented to gender and sexual identity.

Other studies are needed to fully understand the barriers established by doctors and the development of solutions that are acceptable to both parties, doctors and the trans community. 


\begin{tabular}{|c|c|c|c|}
\hline Author & Goal / Method / Sample & Main results & Recommendations \\
\hline $\begin{array}{l}\text { Snelgrove, Jasudavisius, Rowe, } \\
\text { Head, \&Bauer(2012)/ Ontario/ } \\
\text { Canada }\end{array}$ & & $\begin{array}{l}\text { medicine" emerged as a characteristic } \\
\text { in the health care barrier, in addition to } \\
\text { the limited health care options proving } \\
\text { itself as a significant barrier. The notion } \\
\text { that gender identity is a special area of } \\
\text { psychiatry, a fact cited as a barrier by } \\
\text { some psychiatrists working in this area } \\
\text { As much as they agreed on the lack of } \\
\text { education on the health of transgender } \\
\text { people, participants differed in } \\
\text { opinions on training strategies to } \\
\text { address this gap (undergraduate } \\
\text { curriculum, guidelines). }\end{array}$ & \\
\hline $\begin{array}{l}\text { Travers et al. (2010) / Toronto / } \\
\text { Canada }\end{array}$ & $\begin{array}{l}\text { To identify the needs and } \\
\text { concerns of professionals } \\
\text { working with LGBT young } \\
\text { individuals / Qualitative / } 80 \\
\text { professionals. }\end{array}$ & $\begin{array}{l}\text { Professionals identified barriers } \\
\text { to provide adequate support for } \\
\text { the complex needs of LGBT young } \\
\text { individuals, which include: the } \\
\text { extension of the city, the needs of } \\
\text { transgender young individuals, cross- } \\
\text { identities and homophobia within } \\
\text { health care service agencies, cultural } \\
\text { diversity and different religious beliefs } \\
\text { as well are presented as barriers to the } \\
\text { performance of health care services } \\
\text { and to reaching the community. }\end{array}$ & $\begin{array}{l}\text { It is necessary to train and change } \\
\text { the policies of the health care services } \\
\text { agencies; training of professionals } \\
\text { on guidance of cultural diversity } \\
\text { was considered as the main aspect } \\
\text { to provide the access to health care } \\
\text { services for LGBT young individuals. }\end{array}$ \\
\hline
\end{tabular}

Note: LGBT: Lesbian, Gay, Bisexual, Transvestite; SGM: Sexual and Gender Minority.

It shows that the predominance of the method used in the research is qualitative, followed by quantitative and mixed methods; the participants are mostly health care professionals, due to the use of the descriptors, but there are also studies carried out with students from health courses or LGBT+ individuals - on perceptions or opinions about the health care provided by professionals. The studies show the need to provide training to health care professionals to provide a better care to the LGBT+ public, since there are barriers in the humanized care of this group. The curricular base for graduating in the health care field shows a low number of hours, or the lack of disciplines on this type of health care; besides the presence of stigmas, discrimination, and prejudices of the health care students as for the non-heteronormative individuals.

Although these studies point out the need to offer training and development of these professionals considering their university and career formation, no reference in literature was found regarding a movement in the direction of identifying the knowledge, skills, and attitudes required for the specific care of LGBT+ people. Thus, it is difficult to propose training actions capable of supporting health care professionals in terms of technical-scientific capabilities and adequate behavioral repertoire in the provision of health care to the LGBT+ population.

Therefore, the publications seem unanimous about the importance of the qualification of health care professionals to provide a better care for the LGBT+ population, and the concern about the lack of attention to the subject in curricula and in continuing education, however, there is no indication in the literature about which are the competencies to be developed, that is, it does not address training needs analysis, a stage prior to the planning and execution of educational events, pertinent to developing fixes to skills gaps for the 8 appropriate performance of health care practices. 


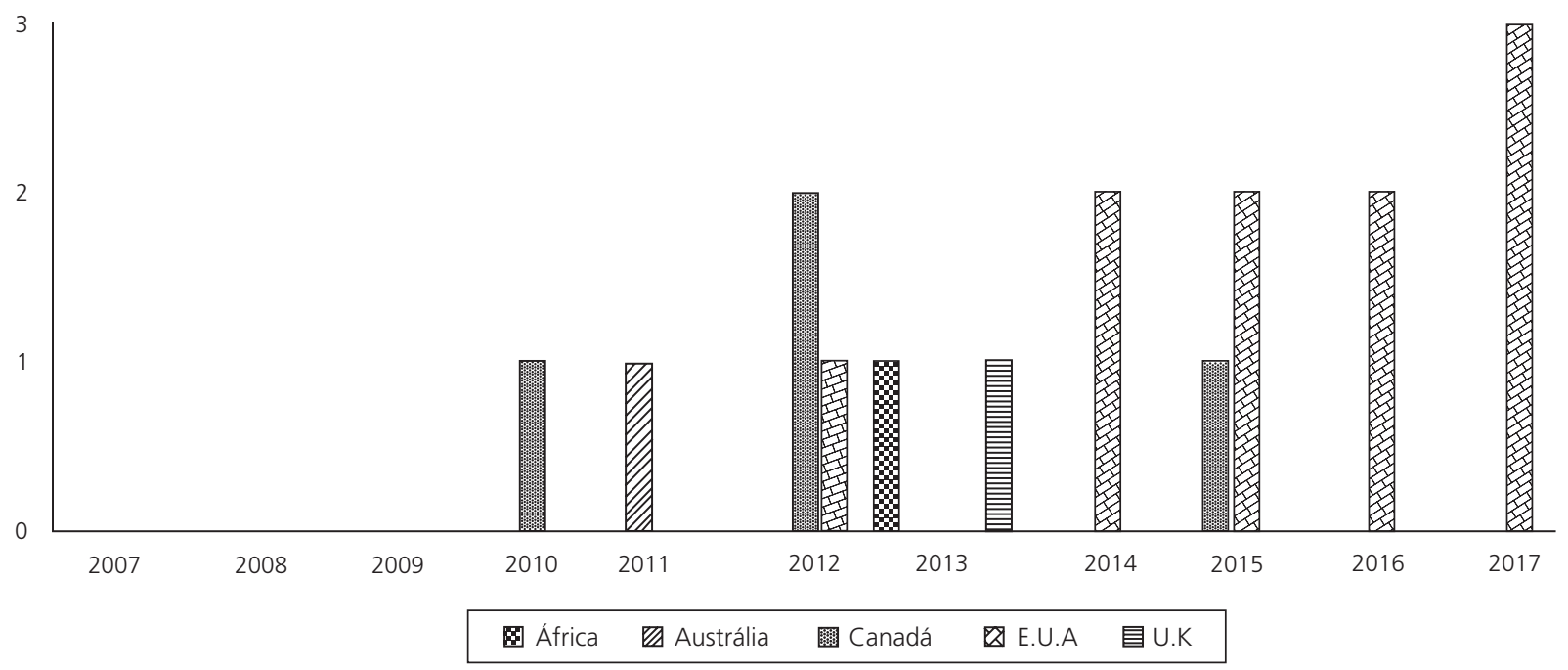

Figure 2. Number of publications by country, from 2007 to 2017, on the subject of training health care professionals in the care of LGBT+ individuals.

Figure 2 shows the countries that published the surveys that integrated the corpus of this review. It is noted that the number of publications has been rising in recent years, with the United States leading the ranking in publications.

This literature review describes the publications of the last ten years on training needs analysis of health care professionals regarding LGBT+ care. It was found that there is a gap on this topic, although there are studies that indicate that some trainings have been performed by health care professionals so that there are changes in the care services offered to this public.

It is mainly the North American countries that publish studies on health care professionals and the LGBT+ public, showing a concern to provide higher quality health care for this population. This concern may be due to the cultural model that governs local society, which is driven by cultural diversity, resulting from minority group claims that have triggered modifications, which can be seen nowadays. On the other hand, there are no publications on this subject in the South American countries, evidencing the neglect of the discussion, and its reflection on health care conditions to the LGBT+ community, disregarding their specific needs, required in medical care, as well as the various forms of violence to which this public is exposed, also in the health care context.

Although there are tools such as "Gender \& Sexual Diversity (GSD)" (Poteat et al., 2017) and "Lesbian, Gay, Bisexual, and Transgender Development of Clinical Skills Scale (LGBT-DOCSS)" (Bidell, 2017) created to guide the training of health care professionals, the process that precedes the training program itself, in other words, training needs analysis, has not yet been described. Similarly, the international literature provides restricted information on training models, covering only aspects about the culture and the ideology of the professional regarding their professional care to the individual (Costa et al., 2018; Grigorovich, 2016; Moe \& Sparkman, 2015; Travers et al., 2010).

Failure to carry out the stage of training needs analysis makes it impossible to visualize the most important skills and the ones health care professionals are most comfortable with (or not) in the care of LGBT+ individuals. If training gaps in the technical and behavioral repertoire of professionals were identified, they could trigger the offer of specific training and improve their quality, influencing the subsequent effective 
performance of these professionals. However, failure to carry out the stage of training needs analysis can lead to a waste of resources, such as training competencies and people who already have them, or failing to train competencies which are of high priority for the adequate performance of these professionals. Both options are considered irresponsible because they directly affect the care of patients according to what is recommended by the World Health Organization.

The GSD scales (Poteat et al., 2017) and the LGBT-DOCSS (Bidell, 2017), which can be used to assess the clinical development of the LGBT+ public, explore specific clinical characteristics, develop or test various training programs and methods related to LGBT+ public, demonstrate to be effective after the training of health care professionals, besides assisting in the identification of other procedures to verify which subject should be emphasized when training professionals regarding the health care to the LGBT+ public.

Although there have been no studies that deal with the stage of training needs analysis for health care professionals in the LBGT+ public service in the literature, there is a description of some interventions performed to health care professionals such as training courses, workshops, and application of scales (Bidell, 2017; Meyer \& Johnston, 2014; Rutherford, McIntyre, Daley, \& Ross, 2012), as well as observations of the changes in the professionals' post-test health care attitudes (Meyer \& Johnston, 2014; Pelts \& Galambos, 2017).

From the standpoint of health care system users, they feel invisible to professionals and report that the discrimination based on their sexual orientation is a barrier to obtaining adequate health care (Moe \& Sparkman, 2015). The existing stigma in the context of care and discrimination, practiced by professionals, broaden the chasm for the humanized care this public seeks (Ash \& Mackereth, 2013). The provision of care to individuals with equality, dignity, and humanism, regardless of their sexual orientation, affects the performance of the professional and, therefore, impacts on the care of the health system user (Beagan, Fredericks, \& Bryson, 2015).

The articles have shown that discrimination and stigma to the LGBT+ public prevails in the health care and academia fields, where homosexuality education still remains a psychiatric concept (Beagan et al., 2015; Snelgrove, Jasudavisius, Rowe, Head, \& Bauer, 2012). On the other hand, homoaffective couples reported experiencing barriers and discrimination of health care professionals in the care of their children, demonstrating the need to sensitize these health care professionals to care for this population and the prevalence of heteronormativity in health care (Chapman, Watkins, Zappia, Combs \& Shields, 2012a). There have been reports by health care professionals about the unfriendly environment for this public and the lack of training in this issue in their work institutions, but they also recognize the need to carry out training in the fields of sexuality and gender diversity for providing the population with adequate health care services.

In general, practitioners have negative attitudes when caring for LGBT+ individuals (Ash \& Mackereth, 2013; Jabson, Mitchell, \& Doty, 2016; Mahdi, Jevertson, Schrader, Nelson, \& Ramos, 2014; Matharu, Kravitz, McMahon, Wilson, \& Fitzgerald, 2012; Poteat et al., 2017; Snelgrove et al., 2012), mainly physicians. When comparing bisexual and transgender individuals, these professionals had lower ratings of negative attitudes to the former than to the latter (Jabson et al., 2016); in the study by Matharu et al. (2012), negative attitudes were evidenced for gay men, not for lesbian, bisexual, transgender and intersex people, which probably arises from the cultural aspects of masculinity.

In view of this evidence, there is a need for health care students to understand how the negative behavior of professionals affects the LGBT+ individuals (Müller, 2013). The study by Pelts and Galambos (2017) showed that a teaching intervention in health care for LGBT+ individuals aimed at health care professionals resulted in changes in their attitudes towards residents who did not identify themselves as heteronormative individuals. This shows that education plays a decisive role in providing adequate information to health care professionals, a fact that assists in the care provided to individuals in this group. Therefore, providing training to health care professionals would trigger a contribution of congruent knowledge to professionals so that they can perform appropriate health care practices. 
The restriction on obtaining references, in the dominant scientific literature itself, with quality to support LGBT+ health care, as well as the restricted terminology of "binary medicine" make it difficult to assist these users in the health care system (Snelgrove et al., 2012). Contrary to this perspective, the professionals who were able to identify the aspects that interfered in their field of action, modifying the context and their own behaviors, are precisely those that had obtained some training in the LGBT+ field or that had already provided health care services for this public (Moe \& Sparkman, 2015).

To increase the quality of care provided, health care professionals need to obtain a greater theoretical and technical base, as well as to develop behavioral skills to facilitate LGBT+ user health care. For this, there is a need to train both students and professionals who are already working in the health care field. In relation to the first group, it is suggested to add specific disciplines in this area to the undergraduate curriculum of health care professionals, since there is only an average of 10 hours (North American context) for a four-year curriculum (Matharu et al., 2012; Müller, 2013). Regarding the second group, it is extremely important to invest in continuing education of these health care professionals who are already working in the area (Ash \& Mackereth, 2013; Carabez et al., 2015; Rutherford et al., 2012).

The suggestion to offer more training opportunities to health care professionals with relevant information regarding the health care context of the LGBT+ community is emphasized in these studies, demonstrating that it is essential to promote teaching and learning accessibility (Czaja et al., 2016; Rutherford et al., 2012). It should be noted that the basic contents, such as the terminology or the use of the proper article and social name, are interventions that culminate in a humanized health care for the individual (Rutherford et al., 2012). Training processes for health care professionals should be maintained for as long as it takes until the existing barriers in the health system are extinguished (Ash \& Mackereth, 2013), and if these barriers stem from the lack of knowledge, skills, and attitudes, i.e., skills gaps, formal actions must be taken within the organization, such as training courses.

Regarding the ideal format for continuing education in this subject, there is a divergence of opinions among health care professionals about the strategies to carry it out and how to prepare future professionals to work in this field. Some suggest revising the undergraduate curriculum; for those professionals who are working, there are suggestions for conducting face-to-face training; others describe the provision of online training as opportune; and also, there are those who suggest the implementation of health care guidelines for the LGBT+ population, so that further training in this context are developed (Ash \& Mackereth, 2013; Beagan et al., 2015; Carabez et al., 2015; Chapman et al., 2012a; Rutherford et al., 2012; Snelgrove et al., 2012). Regardless of the best teaching method or the most opportune moment (during graduation or during the professional activity) to carry out this kind of training, they are necessary to fill skills gaps that allow more effective and humanized interventions, being a concern in the literature. Therefore, the more educational actions are implemented, the better.

The study by Meyer and Johnston (2014) confirms the importance of training for health care professionals and their positive impact in assisting LGBT+ individuals. The report of a paperback pocketbook for Queer individuals (Beagan et al., 2015), which addresses issues such as providing efficient health care to transgender individuals, reinforces the real need for continuing education for health care professionals so that it may result in the adequate quality of care for the users of the health care system. The individuals' own reports on the need to sensitize professionals about the LGBT+ context for a better health care are also presented, reinforcing the need for professional training (Chapman et al., 2012a).

It is fundamental to provide protocols, theoretical models, and guidelines to assist health care professionals in the care of these individuals; in addition to performing training needs analysis, offering health care professionals training in this subject and evaluating the results of the interventions. The DOCSS and GSD scales are indicated as tools to train professionals and verify the effectiveness of these 
actions, but they have not yet been validated in the Portuguese language, a fact that reinforces the need to create a validated instrument in Portuguese to be used in the Brazilian context. In addition, the curriculum for undergraduate health courses need to be revised to include education regarding the health care for the LGBT+ public.

Further studies to be carried out in the field of health and sexual diversity care should involve innovative and rigorous evaluations, with different users of the health care system and its professionals, as well as linking it to the political layer, so that politicians can be engaged in public health policies and processes that result in a better performance in the health care system access, and in the care of the LGBT+ public (Jabson et al., 2016).

\section{Conclusion}

It is concluded that the scientific literature lacks studies on the training of health care professionals to care for the LGBT+ people in a competent and humanized way. Some of the findings reinforce the need to provide training to health care professionals, as well as demonstrate positive aspects resulting from short-term interventions. Cultural and educational factors, stigmas, and discrimination present themselves as barriers to the humanized care, as well as they negatively intensify the mental health of individuals who face them everyday in the context of today's health care environment.

It is recommended that future studies evaluate the health care practices of these professionals, review university curricula, promote training to professionals, and develop manuals to guide practitioners in the exercise of their functions, so that the appropriate access to health care is provided with dignity and humanization for all individuals who require it.

\section{Contributors}

W.R. DULLIUS, study design and planning the research project, obtaining and analyzing data, writing and reviewing the manuscript. L.B. MARTINS, study design and planning of the research project, obtaining and analyzing data, writing and reviewing the manuscript. V.M. CESNIK, obtaining and analyzing data, writing and reviewing the manuscript.

\section{References}

Ash, M., \& Mackereth, C. (2013). Assessing the mental health and wellbeing of the lesbian, gay, bisexual and transgender population. Community Pract, 86(3), 24-27. Retrieved May 25, 2017, from http://www.ncbi.nlm.nih. gov/pubmed/23540015

Arán, M., Murta, D., \& Lionço, T. (2009). Transexualidade e saúde pública no Brasil. Ciência \& Saúde Coletiva, 14(4), 1141-1149. http://dx.doi.org/10.1590/S1413-81232009000400020

Bidell, M. P. (2017). The Lesbian, gay, bisexual, and transgender development of clinical skills scale (LGBT-DOCSS): Establishing a new interdisciplinary self-assessment for health providers. Journal of Homosexuality, 64(10), 1432-1460. http://dx.doi.org/10.1080/00918369.2017.1321389

Beagan, B., Fredericks, E., \& Bryson, M. (2015). Family physician perceptions of working with LGBTQ patients: Physician training needs. Canadian Medical Education Journal, 6(1), 1-14. Retrieved June 14, 2017, from http://journalsscholarsportalinfo.proxy.library.brocku.ca/pdf/19231202/v06i0001/e14_fppowwlpptn.xml

Carabez, R., Pellegrini, M., Mankovitz, A., Eliason, M., Ciano, M., \& Scott, M. (2015). "Never in all my years...": Nurses' education about LGBT health. Journal of Professional Nursing, 31(4), 323-329. http://dx.doi.org/10.1016/j. profnurs.2015.01.003 
Cesnik, V. M., \& Zerbini, T. (2017). Sexuality education for health professionals: A literature review. Estudos De Psicologia (Campinas), 34(1), 161-172. http://dx.doi.org/10.1590/1982-02752017000100016

Chapman, R., Watkins, R., Zappia, T., Combs, S., \& Shields, L. (2012a). Second-level hospital health professionals' attitudes to lesbian, gay, bisexual and transgender parents seeking health for their children. Journal of Clinical Nursing, 21, 880-887. http://dx.doi.org/10.1111/j.1365-2702.2011.03938.x

Chapman, R., Watkins, R., Zappia, T., Nicol, P., \& Shields, L. (2012b). Nursing and medical students' attitude, knowledge and beliefs regarding lesbian, gay, bisexual and transgender parents seeking health care for their children. Journal of Clinical Nursing, 21, 938-945. Retrieved July 20, 2017, from http://journals-scholarsportal-info.proxy.library.brocku. ca/pdf/09621067/v21i7-8/938_namsakshcftc.xml

Costa, A., Rosa Filho, H., Pase, P., Fontanari, A., Catelan, R., Mueller, A., ... Koller, S. H. (2018). Healthcare needs of and access barriers for brazilian transgender and gender diverse people. Journal of Immigrant \& Minority Health, 20(1), 115-123. http://dx.doi.org/10.1007/s10903-016-0527-7

Costa, A. B., \& Zoltowski, A. P. C. (2014). Como escrever um artigo de revisão sistemática. In S. H. Koller, M. C. P. P. Couto, \& J. Von Hohendorff (Orgs.), Manual de produção científica. Porto Alegre: Penso.

Cronin, P., Ryan, F., \& Coughlan, M. (2008). Undertaking a literature review: A step-by-step approach. British Journal of Nursing, 17(1), 38-43. Retrieved July 14, 2017, from https://www.magonlinelibrary.com/doi/abs/10.12968/ bjon.2008.17.1.28059

Czaja, S. J., Sabbag, S., Lee, C. C., Schulz, R., Lang, S., Vlahovic, T., ...Thurston, C. (2016). Concerns about aging and caregiving among middle-aged and older lesbian and gay adults. Aging and Mental Health, 20(11), 1107-1118. http:// dx.doi.org/10.1080/13607863.2015.1072795

Dowshen, N., Meadows, R., Byrnes, M., Hawkins, L., Eder, J., \& Noonan, K. (2016). Policy perspective: Ensuring comprehensive care and support for gender nonconforming children and adolescents. Transgend Health, 1(1), $75-85$. http://dx.doi.org/10.1089/trgh.2016.0002

Ferlatte, O., Salway, T., Oliffe, J. L., \& Trussler, T. (2017). Stigma and suicide among gay and bisexual men living with HIV. AIDS Care, 29(11), 1346-1350. http://dx.doi.org/10.1080/09540121.2017.1290762

Grigorovich, A. (2016). The meaning of quality of care in home care settings: Older lesbian and bisexual women's perspectives. Scandinavian Journal of Caring Sciences, 30, 108-116. http://dx.doi.org/10.1111/scs.12228

Harrell, B. R., \& Sasser, J. T. (2018). Sexual and gender minority health: Nursing's overdue coming out. International Journal of Nursing Studies, 79, A1-A4. http://dx.doi.org/10.1016/j.ijnurstu.2017.12.002

Jabson, J. M., Mitchell, J. W., \& Doty, S. B. (2016). Associations between nondiscrimination and training policies and physicians' attitudes and knowledge about sexual and gender minority patients: A comparison of physicians from two hospitals. BioMed Central Public Health, 16(256), 1-10. http://dx.doi.org/10.1186/s12889-016- 2927-y

Lee, C., Oliffe, J. L., Kelly, M. T., \& Ferlatte, O. (2017). Depression and suicidality in gay men: Implications for health care providers. American Journal of Men's Health, 11(4), 910-919. http://dx.doi.org/10.1177/1557988316685492

Lerri, M. R., Romão, A. P. M. S., Santos, M. A., Giami, A., Ferriani, R. A., \& Lara, L. A. S. (2017). Clinical characteristics in a sample of transsexual people. Revista Brasileira de Ginecologia e Obstetrícia, 39(10), 545-551. http://dx.doi. org/10.1055/s-0037-1604134

Mahdi, I., Jevertson, J., Schrader, R., Nelson, A., \& Ramos, M. M. (2014). Survey of New Mexico school health. Journal of School Health, 84(1), 18-24. http://dx.doi.org/10.1111/josh.12116

Matharu, K., Kravitz, R. L., McMahon, G. T., Wilson, M. D., \& Fitzgerald, F. T. (2012). Medical students attitudes toward gay men. BMC Medical Education, 12(1), 1-7. http://dx./doi.org/10.1186/1472-6920-12-71

Meneses, P., Zerbini, T., \& Abbad, G. (2010). Manual de treinamento organizacional. Porto Alegre: Artmed.

Merryfeather, L., \& Bruce, A. (2014). The Invisibility of gender diversity: Understanding transgender and transsexuality in nursing literature. Nursing Forum, 49(2), 110-123. http://dx.doi.org/10.1111/nuf.12061

Meyer, H., \& Johnston, T. R. (2014). The national resource center on LGBT aging provides critical training to aging service providers. Journal of Gerontological Social Work, 57(2-4), 407-412. http://dx.doi.org/10.1080/01634372.2014.901997

Moe, J. L., \& Sparkman, N. M. (2015). Assessing service providers at LGBTQ - affirming community agencies on their perceptions of training needs and barriers to service. Journal of Gay \& Lesbian Social Services, 27(3), 350-370. http:// dx.doi.org/10.1080/10538720.2015.1051687

Moscheta, M. S., Souza, L. V., \& Santos, M. A. (2016). Health care provision in Brazil: A dialogue between health professionals and lesbian, gay, bisexual and transgender service users. Journal of Health Psychology, 21(3), $369-378$. http://dx.doi.org/10.1177/1359105316628749 
Mott, L., Michels, E., Paulinho. (2017). Pessoas LGBT Mortas no Brasil: relatório 2017. Recuperado janeiro 20, 2018, de https://homofobiamata.files.wordpress.com/2017/12/relatorio-2081.pdf

Müller, A. (2013). Teaching lesbian, gay, bisexual and transgender health in a South African health sciences faculty: Addressing the gap. BMC Medical Education, 13(1), 1-7. https://dx.doi.org/10.1186/1472-6920-13-174

Pelts, M. D., \& Galambos, C. (2017). Intergroup contact: Using storytelling to increase awareness of lesbian and gay older adults in long-term care settings. Journal of Gerontological Social Work, 60(6-7), 587-604. http://dx.doi.org/1 $0.1080 / 01634372.2017 .1328478$

Poteat, T., Park, C., Solares, D., Williams, J. K., Wolf, R. C., Metheny, N., ...Toiv, N. (2017). Changing hearts and minds: Results from a multi-country gender and sexual diversity training. PlosONE, 12(9), 1-16. http://dx.doi.org/10.1371/ journal.pone.0184484

Rojon, C., McDowall, A., \& Saunders, M. N. (2011). On the experience of conducting a systematic review in industrial, work, and organizational psychology: Yes, it is worthwhile. Journal of Personnel Psychology, 10(3), 133-138. http:// dx.doi.org/10.1027/1866-58 88/a000041

Rowan, N. L., \& Beyer, K. (2017). Exploring the health needs of aging LGBT adults in the cape fear region of north carolina. Journal of Gerontological Social Work, 60(6-7), 569-586. http://dx.doi.org/10.1080/01634372.2017.1336146

Rutherford, K., McIntyre, J., Daley, A., \& Ross, L. E. (2012). Development of expertise in mental health service provision for lesbian, gay, bisexual and transgender communities. Medical Education, 46(9), 903-913. http://dx.doi.org/10.1111/j. 1365-2923.2012.04272.x

Snelgrove, J. W., Jasudavisius, A. M., Rowe, B. W., Head, E. M., \& Bauer, G. R. (2012). "Completely out-at-sea" with "two-gender medicine": A qualitative analysis of physician-side barriers to providing healthcare for transgender patients. BMC Health Services Research, 12(1), 110-122. http://dx.doi.org/10.1186/1472-6963-12-110

Talan, A. J., Drake, C. B., Glick, J. L., Claiborn, C. S., \& Seal, D. (2017). Sexual and gender minority health curricula and institutional support services at U.S. schools of public health. Journal of Homosexuality, 64(10), 1350-1367. http:// dx.doi.org/10.1080/00918369.2017.1321365

Teixeira-Filho, F. S., \& Rondini, C. A. (2012). Ideações e tentativas de suicídio em adolescentes com práticas sexuais hetero e homoeróticas. Saúde e Sociedade, 21(3), 651-667. http://dx.doi.org/10.1590/S0104-12902012000300011

Travers, R., Guta, A., Flicker, S., Larkin, J., Lo, C., McCardell, S., \& Van Der Meulen, E. (2010). Service provider views on issues and needs for lesbian, gay, bisexual, and transgender youth. Canadian Journal of Human Sexuality, 19(4), 191-198. http://dx.doi.org/10.1111/j.1365-2524.2009.00866.x

Uman, L. S. (2011). Information management for the busy practitioner: Systematic reviews and meta-analyses. Journal of the American Academy of Child and Adolescent Psychiatry, 20(1), 57-59. http://dx.doi.org/10.1016/j.revmed.2014.05.011

Received: January 31, 2019

Final version: June 3, 2019

Approved: July 1, 2019 